\title{
History of the Humble Oil \& Refining Company
}

The Business History Foundation has now completed its staff for the writing of the history of the Standard Oil Company (N. J.) and the Humble Oil \& Refining Company. For the latter Dr. K. W. Porter has been called from the teaching of American history to spend the next three years in research and writing. He has the able assistance of Mr. Robert E. Ferris, a graduate of the Harvard School of Business.

Dr. Porter wrote the definitive two-volume work, John Jacob Astor, the first publication to appear in the Harvard Studies in Business History. Later he compiled two volumes of letters and other documents of Boston merchants, entitled The Jacksons and the Lees. His general introduction to these volumes and the special introductions to individual documents are notable pieces of historical research. Dr. Porter has also contributed a number of poems to magazines and has recently published a volume of his poetry. He has also just finished a manuscript on the history of the Seminole Indians.

In the history of the West and the Southwest Dr. Porter is quite at home. He has therefore an excellent general background for a study of the history of the Humble Oil \& Refining Company, which has been an integral part of the history of the region since its formation in 1917. This company has been a leader in the exploration for crude oil, in refining, in pipe-line construction and operation, and not least in the purchase of crude oil in its home district. Doubtless an important phase of Dr. Porter's work will be to show the company's great contributions to the winning of the second World War.

To Dr. Porter and Mr. Ferris go the best wishes of their many friends at Harvard. 